\title{
Relating to Ken Kesey's wise man ${ }^{\text {唡 }}$
}

\author{
Varol Akman* \\ Department of Computer Engineering and Information Science, \\ Bilkent University, Bilkent, Ankara 06533, Turkey
}

Received 1 March 1998; revised version 28 March 1999

\begin{abstract}
We take a parable (told by Ken Kesey) and exhibit how it achieves its sublime effect through a sequence of weak implicatures. Interestingly, the implicatures turn out to allude to Richard Rorty's renowned distinction between metaphysicians and ironists. (c) 2000 Elsevier Science B.V. All rights reserved.
\end{abstract}

Keywords: Irony; Metaphysics; Stories; 'What is said'

"For there is no big secret which the ironist hopes to discover, and which he might die or decay before discovering." (Rorty, 1989: 99)

'There should be something you have to say to everybody in our culture that wants to try to relate to you'. It is with these words the interviewer challenges Ken Kesey in an interview reprinted recently (Kesey, 1996: 364). Kesey, in response, tells the following story:

"There was a wise man who lived up in the mountains and all these people wanted him to drop into the mosque and give them the word on Sunday, so he said all right. He showed up on Sunday and there was this huge crowd of people and he got up there and he says, Good people, do you know what I'm going to talk to you about? and they all shouted back No and he says Ignorant people, and he turns around and he leaves. And so they go back up and say Wait a minute, man, you came through too fast for us, drop in again next Sunday ... and he says all right. So next Sunday he's down there and he starts, Good people, do you know what I'm going to talk to you about? and this time they're ready for him and they all yell Yes and he says Good! and he turns around and he leaves. And so finally they say, Look, man, just

For advice on an early version $I$ am grateful to Bruce Fraser.

* Phone: +90 312290 1537; Fax: +90 312266 4126; E-mail: akman@cs.bilkent.edu.tr 
one more time, cause somehow it's slipping past us. So he comes down the third time and starts up there, Good people, and this time they're ready for him ... Some of us do and some of us don't. Good! Let those who do communicate their knowledge with those who do not." [italics in the original]

In this squib, I want to argue that the above story has interesting connotations in terms of societal pragmatics. Specifically, I want to consider it from the vantage point of 'what is said'. I think several readers may find the story familiar and many might have heard it (possibly in different renditions) more than once. I also have a hunch that we comprehend it - or will do so, if this is the first time we are hearing it - rather well. However, when we ask ourselves what is it that we understand, the answer is not obvious. As a matter of fact, thanks to their ironic and metaphorical nature, the wise man's sermons exhibit considerable (poetic) indeterminacy and vagueness. Thus the question: What is really said by Kesey's wise man? What is the message? My argument, to be detailed in the sequel, will be that the story achieves its intended sublime effect through a sequence of weak implicatures, and that, interestingly, these overall turn out to allude to Rorty's (1989) renowned distinction between metaphysicians and ironists. However, before I embark on it, let me say a few things about the general pragmatic outreach of Kesey's story so that my interpretation of it can be better assessed.

Notice, first of all, that it is possible to regard the above story along Malinowskian lines, viz. talking for the sake of talking. In this approach, rather than conceiving the exchanges reported in the story as transfusion of ideas from the mind of the wise man to that of the audience, we treat them as modes of action: these exchanges do not work as instruments of rumination but rather as elements of phatic communion. Evidently, the setup and the motivations of the parties involved (the wise man and the crowd) render this explanation hardly the right one.

For the diehard Gricean, the story has all the ingredients to see the famous maxims at work. Thus, the wise man is not making his contribution as informative as required, and while he is brief and orderly, he is not making an attempt to avoid ambiguity and obscurity of expression. No doubt he is not saying what he believes to be false, but it is difficult to maintain that he is not saying that for which he lacks adequate evidence.

On a related point, the story uses interrogatives not to request information - their major use - but to formulate rhetorical/speculative questions, musings, and guess questions - their auxiliary uses. It is commonly held that the most appropriate response to a question is one that best conforms to the Gricean maxims. In the present case, the questions of the wise man and the crowd's response are at a clash simply because the wise man is not conforming to the maxims. To invert a remark by Blakemore (1992: 115), the point of the wise man's questions is not to indicate that their answers are relevant.

It is also possible to regard Kesey's story as a paradigm instance of weak versus strong communication (in the spirit of Sperber and Wilson). In strong communication, the speaker constrains the interpretation of his utterance so that the hearer takes little responsibility for the choice of contextual assumptions and effects. Weak communication assigns the hearer greater responsibility in the selection of contextual assumptions 
and effects. Seen in this light, the story perfectly exemplifies weak communication.

Now, back to the details of my promised argument. I would like to start by a couple of general observations regarding stories. For instance, Clark (1996: 346) emphasizes the necessity of certain elements in stories:

"Stories need justification. People must agree that: (1) they want this particular person to tell the story; (2) they want this particular story; and (3) they want it told now." [italics in the original]

So, in our example the crowd wanted the wise man to tell the story (in the format of a sermon) and they wanted this particular story (i.e., 'the word', which I take to be shorthand for "the right way of explaining life, universe, and everything" or to be a suitable mix of the Platonic notions of Truth and Goodness and Reality). They wanted it told urgently so that they kept inviting him when it turned out that 'the word' was somehow slipping past them. It did not take the crowd long to realize that the wise man's way of preaching had a different character. Rather than approaching the matter in the usual, expected manner, he chose to steer toward it. This, they came to realize, he did with a certain purpose. When the story was completed (after the third sermon) a final stage was reached, at which point "the audience is expected to take it [the story] up, alter it, decline it, or even withdraw" (Clark, 1996: 350).

PEOPLE'S STATE

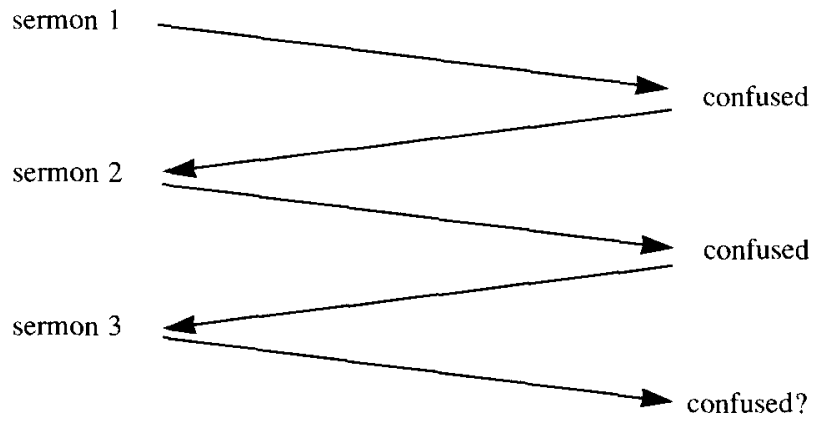

Fig. 1. State transitions in Kesey's story.

Consider Fig. 1, where the structure of the story is modeled as a temporal diagram. After the two 'unhappy' sermons which left the crowd in a more or less muddled state came the third sermon. Maybe it is still possible to argue convincingly that even this sermon did not do enough to clear the air of confusion - hence the question (withdrawal) mark in Fig. 1 - but I'll reason that we are now in a better position to claim that the crowd might take up the message (or decline it, for that matter). Essentially, my argument will be based on the premise that the content of this story is a prime illustration of 'irony' in the general sense of Rorty (1989).

Rorty's theory of irony is a multi-faceted one and here I'll be content with employing a somewhat simplified version of it. Basically, I'll only use his distinction 
between metaphysicians and ironists. According to Rorty, metaphysicians believe that there are real essences out there waiting to be discovered. For the metaphysicians, there is a timeless order which determines the purpose of human existence. Ironists, by contrast, believe that nothing has a real essence. The metaphysician is "someone who takes the question "What is the intrinsic nature of (e.g., justice, science, knowledge, Being, faith, morality, philosophy)?' at face value" (Rorty, 1989: 74), that is, someone who thinks that

"although we may not have all the answers, we have already got criteria for the right answers. So he thinks 'right' does not merely mean 'suitable for those who speak as we do' but has a stronger sense the sense of 'grasping real essence'. (Rorty, 1989: 76, italics added)

By contrast, ironists do not see the point of hankering for notions like 'reality' or 'real essence'. They take final vocabularies which put all doubts to rest with a large grain of salt. Accordingly, for an ironist the situation is as follows:

"There are only little mortal things to be rearranged by being described. If he [the ironist] had been alive or sane longer, there would have been more material to be rearranged, and thus different redescriptions, but there would never have been the right description." (Rorty, 1989: 99, italics added)

Even this unadorned presentation of Rorty's antipodal division is sufficiently inciting to suggest that our wise man must be an ironist at heart. His blunt reactions in the first sermon ('Ignorant people') and the second sermon ('Good!'), and his refusal to continue with the sermons in both cases are essentially vivid - albeit callous - insinuations as to the futility of giving 'the word': the wise man knows that seeking 'the word' is a hopeless endeavor. Anybody in the crowd who anticipates that there is a well-grounded answer to such deep puzzles should be a metaphysician. When the time comes for the final sermon, we sense that the people are ready for him. But the sermon is again brief and can best be paraphrased as follows: to communicate the fact that a search for 'the word' is vain with those who do not (yet) realize this. In other words, the ironists in the crowd should teach the metaphysicians in the crowd that there could never have been the right answer (or the true path or what have you).

I find it reassuring to see that this analysis is also supported by the continuation of the interview (Kesey, 1996: 365). After listening to the story, the interviewer, apparently not satisfied with Kesey's seemingly evasive move, insists: 'Well, let's do that. Communicate your knowledge with those who do not'. To which Kesey's reply is unequivocal:

"I just did it. It's true, man, it's all I've got, I mean, I know more about my brother's creamery than I do about the revolution. You can't expect me to know stuff about ... I don't know that stuff." [italics added]

Not surprisingly, Kesey is an ironist too!

To conclude, "one cannot understand one's partners in dialogue unless one has a good grasp of their word-and-world context". This advice of Mey (1993: 303) re societal pragmatics has been illustrated with a parable which makes a certain 
demand (i.e., the proper philosophy of life) on an audience in order to be properly understood. It is not always that one needs - albeit in the background - a particular philosophical stance in order to make the correct sense of a simple parable. I will have succeeded in my goal for this squib, if I have convinced the reader that philosophical worldviews must be important concerns in pragmatics.

In writing this squib, I kept in mind that it is to be somewhat controversial; it must evoke at least a few cries of 'No, that's not it at all!' I invite those who are annoyed to see relativism lurking in every corner of this squib to provide their own plausible interpretations of the story. As Rorty would have said, the point is to keep the conversation going rather than to find objective truth (Rorty, 1979). And if you think you had espied some pragmatic philosophy and not enough pragmatics in my piece, I hasten to add that there may be more depth in this little story for those interested in dialogues governed by norms, politeness, face-saving, and turn-taking. But let this swirl do for now.

\section{References}

Blakemore, Diane, 1992. Understanding utterances. Oxford: Blackwell.

Clark, Herbert H., 1996. Using language. Cambridge: Cambridge University Press.

Kesey, Ken, 1973. Kesey's garage sale. New York: Viking.

Kesey, Ken, 1996. From 'Ken Kesey was a successful dope fiend'. In: John Clark Pratt, ed., One flew over the cuckoo's nest: text and criticism. New York: Penguin. (This interview appears in full in: Kesey, 1973.)

Mey, Jacob L., 1993. Pragmatics: An introduction. Oxford: Blackwell.

Rorty, Richard, 1979. Philosophy and the mirror of nature. Princeton, NJ: Princeton University Press. Rorty, Richard, 1989. Contingency, irony, and solidarity. Cambridge: Cambridge University Press.

Varol Akman is a Professor of Computer Engineering at Bilkent University, Ankara. His current research is concentrated on explicating the notion of context. From 1980 to 1985, Akman was a Fulbright scholar at Rensselaer Polytechnic Institute, Troy, New York, where he received a Ph.D. degree in computer engineering. Prior to joining Bilkent in 1988, he was a senior researcher with the Center for Mathematics and Computer Science, Amsterdam. 